\title{
LA TERRITORIALIZACIÓN DEL OTRO: \\ espacio urbano, segregación y cuerpos infames en Rosario, Argentina
}

\author{
A territorialização do Outro: espaço urbano, segregação e corpos \\ infames em Rosario, Argentina.
}

Cecilia María

\section{PASCUAL}

Facultad de Humanidades y Artes, Rosario, Argentina https://orcid.org/0000-00028206-087X cecipascual@hotmail.com

\section{RESUMEN}

El presente artículo construye una mirada histórica sobre el proceso de configuración de áreas urbanas segregadas basadas en principios y lógicas de diferenciación y exclusión. La espacialidad es abordada a través de la observación de sentidos aplicados por lentes normativas sobre los cuerpos y prácticas tipificados como infames, peligrosos y abyectos. La abyección como marca indeleble permite visualizar la conexión existente entre lo anómico o anormal y una imaginación sobre la regularidad que acompaña las construcciones de sentido sobre un deber ser de ciudad moderna. Metodológicamente estos sentidos son aislados tras la triangulación de tipos documentales (prensa, documentación oficial, discurso médico) para contrastar la efectividad de los intentos normativos con los órdenes de prácticas observados. Asimismo, el artículo permite comprender la variabilidad de las construcciones sobre los cuerpos otros y los espacios que habitan y la conexión entre esos otros y aquellos adscriptos a un orden nombrado como regular.

Palabras Clave: Ciudad-Cuerpos-EspaciosSegregación.

\section{RESUMO}

Este artigo constrói uma perspectiva histórica sobre o processo de configuração de áreas urbanas segregadas baseadas em princípios e lógicas da diferenciação e exclusão. A espacialidade é abordada através da observação de sentidos aplicada por órgãos reguladores sobre os corpos e práticas classificados como infames, perigosos e abjetos. A abjeção como marca indelével permite visualizar a ligação entre o anômico ou anormal e a imaginação sobre a regularidade que acompanha as construções de sentido sobre um deve ser da cidade moderna. Metodologicamente, esses sentidos são isolados após a triangulação de tipos de documentos (jornais, documentos oficiais, discurso médico) para contrastar a efetividade dos esforços regulatórios com as ordens de paráticas observadas. Além disso, o artigo permite compreender a variabilidade das construções sobre os outros corpos e os espaços que habitam, bem como a conexão entre esses outros e aqueles atribuídos a uma ordem nomeada como regular.

Palavras-Chave: Cidade; corpo; espaços; segregação. 


\section{Introducción: Metáforas espacializadas de la infamia}

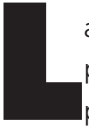

a tipificación espacial de las zonas urbanas con cualidades que exaltan lo negativo, peligroso, inmundo y contaminado comporta un correlato material sobre los cuerpos de aquellos involucrados en sus lógicas. Usualmente, el carácter ignominioso de un área, foco o porción de la ciudad está asociado a hábitos, condiciones, prácticas e inscripciones que implican definiciones claras o difusas sobre las relaciones humanas, las actividades económicas y los sujetos específicos que las pueblan. La otredad es, junto con la petición de distancia, el contenido de los procesos de segregación de los cuerpos infames (FOUCAULT, 1996) y de lo que, según Senett (1997), provoca temor al contacto. Tal otredad se asimila, de modos peculiares en sociedades y momentos históricos diferentes, a lugares caracterizados como márgenes o confines. Esos sitios se adscriben asimismo a prácticas e individuos que exhiben una desviación con respecto a un conjunto de normas (FOUCAULT, 2010). El higienismo primero y la medicina social luego fueron los condensadores e irradiadores de los sentidos que asociaron la peligrosidad de los cuerpos con ciertos espacios y viceversa. La mirada medicalizadora fue la encargada del ordenamiento de esa manifestación de contornos difusos, heréticos y mágicos encarnados en la enfermedad (ROSENBERG, 1992). A fines del siglo XIX, una serie de imágenes potentes alrededor de la no conveniencia de la contigüidad espacio-existencial entre hombres sanos y enfermos inundaron la construcción de sentido sobre lo urbano. También, esos mismos sentidos, primigeniamente en el siglo XIX aun se hallaban contiguos a otras manifestaciones vulneradoras de la norma como las prácticas sexuales denominadas disolutas o, los criminales, los alienados, los mendigos y los pobres (SALESSI, 1995). Todas estas prácticas que podríamos calificar de heterodoxas eran indiferenciadas en un discurso, la prensa y la voz municipal, para nombrar aquello que escapaba a itinerarios previstos y regulados. Luego, funcionaron y funcionan aun expurgados de sus contextos de enunciación, en los argumentos que entornaron las normativas, la prensa y la literatura. La otredad revela aristas no humanas adjudicadas al sujeto de imputación sobre el que se coloca. Es posible que este proceso de discriminación de espacios y sujetos pueda rastrearse en los avatares históricos de muchas ciudades, al menos latinoamericanas, con cualidades comparables. No obstante, se escogió como observatorio una ciudad intermedia al sur del continente americano. El locus en el que se delimitaron estos contenidos es la ciudad de Rosario (segunda o tercera en importancia) en Argentina. Se trata de una ciudad portuaria consolidada a instancias de la migración ultramarina en el último tercio del siglo XIX acusando una veloz complejización de sus estructuras socio urbanas. La periodización observada coincide con el ciclo de consolidación urbana liberal entre finales del siglo XIX y el primer tercio del siglo XX. En todos los ejemplos que aquí se proponen, la humanidad se encuentra reñida con un estatuto semibestial que quiere conjurarse mediante intervenciones normativas. Los cuerpos de aquellos sujetos involucrados en este artículo poseen un estatuto monstruoso (FOUCAULT, 2000, p. 68). Constituyen una mezcla morfológica que compone sin 
solución de continuidad a la vida, la muerte, lo animal, lo humano, lo apolíneo, lo defectuoso, la belleza, la fealdad, lo virtuoso, lo pecaminoso. ¿Cómo se construyeron imágenes tan dispares sobre ciertas prácticas y actividades fijadas al estatuto corporal? Para intentar ofrecer una explicación a este interrogante, se focaliza en las formaciones de sentido como maneras de visibilizar, invisibilizar o denotar la presencia de otros. La propuesta consiste en mostrar las maneras en que emerge la distancia simbólica en la ponderación del cuerpo excluido, que aumenta y recrea la segregación espacial trazando confines, itinerarios y sitios más o menos prohibidos o vedados en la trama urbana que muchas veces se acoplan a la idea de desorden. La marginación de cuerpos en el espacio material y simbólico no se articula necesariamente con la desposesión. No obstante, son dos registros que se ajustan y complementan perfectamente para la definición negativa. La construcción simbólica de un «marginal» opera tras la edificación de un estigma, que expresa la relación establecida entre un atributo en relación con un estereotipo (GOFFMAN, 2006) cercano a una determinada concepción de normalidad (MACHEREY, 2011).

Aquí no se practicará una genealogía detallada de los universos de prácticas escogidos o de las instituciones revisadas en su dinámica de configuración histórica. Se tomarán fragmentos de sentido presentes en los materiales documentales para mostrar las significaciones aludidas. Es decir, ni la hospitalización, el encierro, la muerte, la locura y la prostitución serán narradas exhaustivamente como procesos separados, (cuestión ya abordada por la historiografía nacional) sino que se exaltará lo que tienen en común para componer metáforas de la degradación, la estigmatización y la segregación. Estas prácticas son examinadas como constitutivas de la lógica espacializadora en la ciudad. Es decir se abordan como expresión del crecimiento urbano que delimita y compone áreas específicas para el funcionamiento. Se propone leer la textura normativa de las intervenciones sobre el espacio urbano para visualizar la intersección entre lugar y cuerpo. Es en el funcionamiento efectivo de la norma y en los pliegues de la articulación discursiva donde podemos pensar en torno a los contenidos de los universos simbólicos de separación.

\section{Hospital e infección. Distancia y anomalía}

A ntes de 1897, la separación de los enfermos considerados peligrosos comportaba formas difusas. De manera sistemática, estos individuos eran llevados a salas repletas de otros similares en los precarios establecimientos que el municipio tenía su disposición. Asimismo, durante momentos álgidos de infección, ya fuera colérica o diftérica, tifoidea, sarampiónica o variólica el panorama se dividía entre la exaltación, la acumulación de cuerpos enfermos en sitios fétidos, oscuros y pequeños, y la dilación de la denuncia o el ocultamiento de la situación ante las autoridades sanitarias. El cuerpo infectado era asociado rápidamente con la anomalía. Es decir, con un estado extraño que obtenía visibilidad coyunturalmente. No obstante, la actitud normativa adquiría, con mayor frecuencia, los signos del desperfecto. Encarnado en la zona central, el conventillo albergaba sistemáticamente a inquilinos enfermos, incluso algunas piezas oficiaban de lazareto de emergencia 
dando cobijo a los afectados por las dolencias infecciosas. Eran frecuentes las escenas que involucraban corridas, niños afiebrados deambulando por los patios, animales de corral alborotando los lechos de los enfermos.

En 1890, bajo la intendencia de Gabriel Carrasco, la cuestión de la infección y el peligro de su propagación cobraron relevancia en las intervenciones del gobierno local. Frente a una escalada importante de los casos de difteria, se anunciaron medidas sistemáticas para diagnosticar la situación de los enfermos infectocontagiosos, sus lugares de habitación y las posibles maneras de prevención y resguardo del resto de la población. Se visibilizaba a la Casa de aislamiento como un local donde deberían situarse a los enfermos de esta dolencia. El aislamiento de los atacados era el plan circunstancial, mientras no se operase un saneamiento integral de la ciudad afectada de manera permanente por esta enfermedad. El problema más importante era la dispersión y las variadas estrategias desplegadas por los atacados para no caer en el encierro involuntario, dentro de un establecimiento todavía bastante dudoso y del que no se tenía ninguna certeza de salir con vida. El diagnóstico apuntaba a la identificación del atacado de extracción social popular como un sujeto que conspiraba constantemente contra sí mismo y contra el resto de la comunidad. Mediante la evasión persistente de la vigilancia médica, obstaculizada por la residencia móvil, cambiante y atiborrada de los conventillos, era imposible una erradicación de la multiplicación de focos de infección y el aislamiento forzoso de sus componentes. ${ }^{1}$

Entonces, las dos caras de la espacialización segregada de los enfermos infectocontagiosos del municipio fueron el conventillo y la Casa de aislamiento. Se sostenía que el control no podía desplegarse sin un equilibrio entre estas dos formas de albergue de personas pobres.

[...]debe ser obligatorio sobre todo para las casas de inquilinato, con desalojo inmediato de las mismas y desinfección del local, penándose con una severa multa a los gerentes de esas casas que ocultan a los enfermos [...] Desgraciadamente, esta medida de tan alto interés se halla dificultada por ciertos derechos individuales que todo enfermo opone cada vez que se trata de conducirle a la Casa de Aislamiento. ${ }^{2}$

En 1895, durante la intendencia de Alberto Paz, quien también llevaría adelante el único censo de conventillos y establecimientos insalubres realizado en el municipio durante el período analizado, comenzó la construcción del local destinado a funcionar permanentemente como Casa de Aislamiento (en adelante, CA). ${ }^{3}$ Este sitio fue erigido sobre la actual calle Avellaneda, en el segundo anillo de bulevares, convenientemente alejado entre tres y cuatro kilómetros del entorno central de la ciudad. La zona, en el momento de la localización de la CA, semejaba un descampado rodeado de algunos establecimientos productivos. Un año después ya se hallaba terminada la primera sección con capacidad para alojar a ochenta enfermos y puesta bajo la organización de las hermanas provinciales del Huerto. ${ }^{4}$ Esta institución era representada como una herramienta eficaz para la supresión de la dispersión de los focos en la trama urbana, concentrando y ofreciendo la posibilidad 
de contabilizar el caudal y encapsular el poder de las amenazas infectocontagiosas. ${ }^{5}$

El procedimiento de internación en la CA estaba focalizado en los enfermos pobres. ${ }^{6}$ Se admitía a todo aquel que se presentase a las instalaciones previa constatación del carácter infeccioso de la dolencia. ${ }^{7}$ Como espacio de excepción, se observa la prohibición del ingreso de elementos de juego, de bebidas espirituosas y/o alimentos. Esta regla especial indica la irregularidad detectada en algunas ocasiones respecto al ingreso de pacientes con efectos personales a las dependencias. Una vez ingresados, los pacientes entraban a una lógica de desposesión completa. Según el tipo de enfermedad observada, se les asignaba un número de ingreso y una zona específica. La entrada a la CA componía una metáfora de saneamiento y limpieza que culminaba con la casi segura defunción y la poco probable cura del damnificado. ${ }^{8}$ La vida cotidiana dentro de la Casa de Aislamiento estaba regulada por operaciones específicas que se focalizaban en la conducta moral del paciente. Los infectados debían mantenerse limpios, colaborar en el aseo de los espacios que ocupaban y no podían abandonar el establecimiento sin una autorización previa, que en estado de convalecencia era casi imposible que se les concediese. La mayor tecnología disciplinaria, que denota la distancia simbólica con que se significaba a los ingresados, estaba vinculada con las visitas, es decir con la relación con el afuera. El acceso de los allegados al enfermo a la CA era casi siempre circunstancial, escaso y mediado por una cantidad de requisitos y prevenciones que enfatizaban la peligrosidad de la aventura. En primer lugar, las visitas sólo se autorizaban cuando la situación del paciente era cuasi agónica. Entonces, por pedido del interno, algún familiar o representante de su culto podía ingresar a saldar las "cuentas que hubieran quedado pendientes". En segundo lugar, el protocolo señalado para la visita refuerza las significaciones en torno a la distancia del cuerpo contaminado. Al ingresar, el visitante era recibido en un salón exclusivo, donde se le hacían una serie de preguntas vinculadas a su salud en general y a una especie de historia de su sistema inmunológico, seguida de las vacunas pertinentes en caso necesario. Superado este nivel, y advertido el visitante de la peligrosidad de la situación, se procedía a la desinfección mediante una solución de las extremidades y el rostro, además de la colocación de una capa de cuero que cubriese por completo sus ropas. ${ }^{9}$ Ya en la habitación donde yacía el paciente, se aconsejaba mantener una distancia prudencial de la cama, no hablar directamente a la cara y evitar el contacto físico. La audiencia con el enfermo era breve- no más de quince minutos- y culminaba con una nueva desinfección del cuerpo de la visita, así como la recomendación enfática de no abordar vehículos públicos, manipular alimentos o niños hasta pasadas las dos horas del encuentro.

En la práctica, probablemente la laxitud gobernara este rígido protocolo higiénico. No obstante, resulta pertinente observar las representaciones que entornaban la tecnología normativa, dotando de un estatuto específico al cuerpo de quien, aislado, perdía inmediatamente su estatuto de sujeto-humano para convertirse en un objeto peligroso, portador de un mal de dimensiones inconexas, silente, pero todavía extraordinario y salvaje. Hacia 1907, la precariedad de la CA fue puesta de manifiesto frente a los casos de peste bubónica 
que seguían bajo la lupa, aun pasada la coyuntura álgida de 1900 (PRIETO, 1996). Durante el brote epidémico de bubónica, la CA se amplió creando un pabellón para variolosos, dejando un amplio sector antes destinado a autopsias para los afectados por la peste..$^{10} \mathrm{El}$ aislamiento tibiamente garantizado por la casa fue trasmutado por la estigmatización fuera de ella. Se cursaron numerosas órdenes de quema y cerco de una casa de inquilinato céntrica, declarada como foco tras haberse detectado numerosos casos. ${ }^{11}$ Incluso se denunciaba, desde las páginas de La Capital, que la situación que vivía Rosario podía parangonarse con la India, poniendo a rodar estimaciones preconcebidas y prendadas de la exotización propia del orientalismo (SAID, 2002), de lo que sería un espacio contaminado, inseguro y peligroso y poblado de cuerpos enfermos.

Hoy la enfermedad se ha posesionado de la manzana: nos consta
[...] mañana, sino ya mismo, la infección habrá llevado sus funestos
gérmenes al corazón mismo de la ciudad, posesionándose de
todas sus arterias y convulsionando todo su organismo. Aparte de
los enfermos que han ingresado a la Casa de Aislamiento, existen
otros en la ciudad cuyo paradero se desconoce. A este respecto
conviene hacer resaltar los peligros que encierra muchas veces el
deber facultativo de discreción que impide saber con certidumbre
la radicación del peligro infeccioso. ${ }^{12}$

El semanario de variedades, Monos y Monadas, se sumó a la campaña de denuncia de las autoridades sanitarias de la ciudad, delineando con su peculiar tono satírico el perfil de los individuos internados en la CA. Allí se establece una caracterización de inmovilidad. El Infectado sería una presa sitiada por el microbio que ya no podría deshacerse del estigma que el hecho de habitar en ese espacio le ha conferido. Una serie de binomios operan como elementos signícos: la oscuridad mortuoria confrontada con la vida de un rayo de sol, el aire contra el estancamiento de las cuatro paredes de la CA, el aspecto gris, macilento y precario de la construcción ante una arquitectura hospitalaria henchida de colores y de líneas atractivas a la vista. ${ }^{13}$ Hasta 1914, el establecimiento conservó el nombre de CA. Luego, en honor al Intendente Gabriel Carrasco, tomó su nombre antecedido por la designación de Hospital, que conserva hasta la actualidad. Su esfera de acción incluyó la atención de enfermos infectocontagiosos de localidades y pueblos aledaños con la consigna del aislamiento. La lepra y la tuberculosis fueron las enfermedades insignia del tratamiento en sus instalaciones reforzando el estigma anteriormente asignado al espacio hospitalario con las conocidas representaciones negativas que portaban estas dolencias (ARMUS, 2007). Las diferentes enfermedades infectocontagiosas registradas en el municipio muestran tanto una temporalidad particular atada a una espacialización específica. En la década de 1920, las instalaciones de este establecimiento eran ruinosas, como ya hemos referido en relación a los servicios sanitarios de la ciudad. La prensa retrataba casi diariamente la deficiencia de recursos e instalaciones que frente al aumento de la demanda por parte de enfermos pobres se hallaba sometida la oferta hospitalaria. ${ }^{14} \mathrm{El} \mathrm{Hospital} \mathrm{Carrasco} \mathrm{recibía} \mathrm{diariamente}$ cientos de enfermos, sobre todo de tuberculosis, sumidos además en una notable miseria material. Además, dentro de los afectados por enfermedades "ignominiosas", figuraban los enfermos de cáncer que debían ser sometidos a cirugías, sumando una dolencia de etiolo- 
gía y cura incierta ${ }^{15}$ cuyas cualidades negativas eran muy potentes (SONTAG, 2002). Hacia 1927, en el establecimiento se hacían estas intervenciones quirúrgicas en un improvisado galpón con techo de zinc, sin más comodidades que una camilla asentada sobre cemento alisado. ${ }^{16}$

En el contexto de esta peculiaridad, detectada por algunos ediles en el seno del HCD, puede observarse por primera vez una alocución que pone en suspenso la localización del establecimiento para infectocontagiosos. ${ }^{17}$ Frente a la presunta donación de terrenos para la construcción de un establecimiento hospitalario, a unas veinte cuadras del Hospital Carrasco, en el barrio Belgrano, además de la idea de sistematización sanitaria diagramada por el médico higienista Manuel Pignetto, se discutía la pertinencia de refaccionar o no el antiguo Lazareto. ${ }^{18}$ En esta ocasión el concejal Esteban Morcillo argumentaba que: "sería buen momento para llevar este Hospital de Contagiosos a un lugar más alejado", 19 explicitando que el radio urbano para este tipo de establecimientos ya no coincidía con las supuestas condiciones de lejanía y aislamiento. Poco a poco, en el transcurso del debate, quedaba en evidencia la valoración casi unánime sobre la peligrosidad del foco de acumulación de contagiosos en una zona que había sufrido un proceso de poblamiento importante. ${ }^{20} \mathrm{El}$ 23 de noviembre de 1927, se sancionó una ordenanza que establecía la creación de dos pabellones para leprosos en el Hospital Carrasco. Ante la inminencia de la sanción, se desató un revuelo entre los vecinos de la sección octava del municipio, apoyados por algunos concejales. ${ }^{21}$ Los residentes expresaron caracterizaciones negativas sobre los asilados. ${ }^{22}$ Como resultado de una asamblea, los vecinos elevaron una carta al Concejo Deliberante (HCD) para intentar frenar la ejecución de la ordenanza. Evidentemente, la cuestión leprosa implicaba niveles de impureza y peligro. ${ }^{23}$ Se argumentaba que la zona había crecido en demasía y que conformaba un pujante centro comercial y social hacia el Oeste del municipio. La existencia de escuelas y de múltiples comercios y casas de familia constituían la justificación para impedir la existencia de un leprosario en el Hospital Carrasco. Además, se señalaba que esta institución, frente a la escasez de servicios hospitalarios, había sido tomada como un centro de clínicas donde los vecinos pobres y no tan pobres iban cotidianamente a hacerse atender por dolencias menores. El repulsivo espectáculo de la "muerte en vida", protagonizado por estos enfermos de aspecto abominable no podía ser tolerado por los vecinos. Es preciso detenerse en las argumentaciones que aparecen sobre el cierre del mensaje epistolar. Existe una peculiaridad que no se ha contemplado. A diferencia de otros enfermos infectocontagiosos, los atacados de lepra congregaron dos cualidades que exaltaban su carácter "estigmatizable". Por un lado, poseían un aspecto monstruoso, dadas las marcas que esta enfermedad deja sobre la piel, incluyendo protuberancias nudosas en el rostro y las extremidades, que visualmente ofrecían una imagen incontestable de su condición. Por otro lado, los enfermos circulaban en los jardines del Hospital, a la vista de los transeúntes y en ocasiones podían, según el avance de su tratamiento, hacer algunas salidas recreativas por la zona. La doble posibilidad de hacer contacto visual con esas pieles estragadas o de rozarse imperceptiblemente en la calle constituían un atentado a la moral 
y a la salud pública. La lejanía, el ocultamiento y la normalización eran la conjura (SENETT, 1997) para esta percepción de contaminación simbólica.

\section{Camposanto, segregación y estigmatización}

La relación entre el hombre y la muerte posee una complejidad insondable. Los vínculos que se establecen entre las subjetividades, el cuerpo yerto y los espacios para su guardado en las ciudades resultan tal vez más asibles. Los cementerios y enterratorios constituyeron, desde el siglo XVIII y especialmente durante el XX, los objetos principales de segregación de la trama urbana. Formaban parte del mismo estatuto de insalubridad que se le asignaba a las fábricas y a los hospitales (WILDE, 1878; RAWSON, 1876). Rosario no ha sido la excepción. Aquí interesa bosquejar las significaciones que existieron en torno a la tensión entre cuerpo muerto y espacio, haciendo hincapié en la localización de los cementerios y en las disposiciones relativas a la distancia como organizadora de la espacialidad del tabú sobre la muerte. Es decir que se focalizará sobre los avatares de la conexión o desconexión de uno de ellos, el más apartado hacia el oeste de la traza, y lo que representaba como figura urbana.

Dos construcciones son relevantes en términos de localización para la guarda de la muerte en la ciudad. ${ }^{24}$ El cementerio "El Salvador", el más antiguo de Rosario, fue inaugurado a mediados del siglo XIX (1856) frente a los terrenos de lo que más tarde (1900) sería el Parque Central más importante de Rosario (ROLDÁN, 2015). Esta construcción relevó al camposanto ubicado en las proximidades de la Estación de trenes Rosario Central que había asumido como sitio sagrado de entierro, luego de las prohibiciones a comienzos de 1800 para enterrar en las inmediaciones de la iglesia catedral. ${ }^{25}$ Frente al crecimiento poblacional y a la imposibilidad de ampliar las instalaciones por peligro de desmoronamiento de las barrancas, se decidió erigir un enterratorio en lo que en ese momento era el sitio más alejado de la plaza central. El otro cementerio al que referiremos aquí es "La Piedad" o cementerio nuevo. Fue inaugurado en 1886 como enterratorio municipal en la coyuntura de la epidemia de cólera de 1886/87. ${ }^{26}$ La necesidad de enterrar mayor cantidad de cuerpos y la masividad de la amenaza infectocontagiosa definieron la localización al oeste en el límite del municipio. No obstante, durante diciembre de 1886, momento donde se registraron mayor cantidad de muertes se propuso ordenar el enterramiento especial de coléricos a veinte cuadras del nuevo enterratorio. En ese contexto, el cuerpo era un objeto contaminante en sí mismo si permanecía sin sepultura, por lo cual superadas las epidemias coléricas de 1886/7 y 1895, una ordenanza reguló el tratamiento del cuerpo infectado en los velorios. La habitación donde había yacido el enfermo, en caso de no haberse consumado la defunción en el lazareto, no podía ser habitada por más de tres personas en simultáneo, debiendo permanecer el cadáver envuelto en mantas y rociado con desinfectante hasta se hiciese presente alguna autoridad sanitaria que ratificase el deceso. Todos los muebles serían confiscados para la desinfección. No más de diez horas duraría la comunión de personas en torno al muerto. El aislamiento nominal que implicaba la enunciación de 
una muerte por enfermedad infectocontagiosa era traspasado al lugar del último suspiro. La permanencia en contigüidad espacial con aquello que estaba supuestamente apestado, ya que no necesariamente toda la habitación contenía los microbios letales, se acotaba en el tiempo del velatorio para restringir la posibilidad de contagio. Podría pensarse que, en parte esta era una solución cuasi simbólica de control en el contacto con el muerto, ya que una medida radical, como ocurrió sólo en los momentos álgidos de las epidemias, hubiese sido lo más ajustado. Las ideas alrededor de lo que significaba permanecer en contigüidad con el cuerpo de un varioloso, leproso, etc., implicaba una regulación que expresaba una diferenciación con otras maneras más "limpias" de muerte, para las que los velatorios duraban hasta veinticuatro horas.

El cementerio antiguo "El Salvador", que con el tiempo quedó encorsetado en la zona urbana central, adquirió el lugar de patrimonio histórico de la muerte al albergar las tumbas de las figuras más notables de la ciudad. No obstante, su funcionamiento siguió adelante mediante ampliaciones y modificaciones en su estructura. La Piedad o el antiguo enterratorio municipal fue nombrado como el "cementerio de los pobres"27 y, además, cobijó un elemento de peculiar importancia para la tecnología de eliminación de cadáveres en el siglo XX: el horno crematorio. Como se señalaba, la lejanía connotó peculiarmente a La Piedad mediante la doble estigmatización de pobreza y distancia. ${ }^{28}$ Hasta 1911, aproximadamente las visitas de los deudos a este camposanto se hacían a pie o a través del alquiler de coches. Salvando el espectáculo extraordinario de los enterratorios que trasladaban en carros al muerto y a sus familiares cercanos, habitualmente la zona estaba desierta. No llegaba ninguna forma de transporte público a La Piedad. Excepciones configuraban, por ejemplo, el festejo de día de los muertos donde cientos se agolpaban a las puertas del cementerio después de marchar en procesión gran cantidad de cuadras hacia el suburbio oeste de la ciudad. Allí, la atmosfera despoblada y grisácea de la calles de tierra apisonada se veía quebrada por el ornamento de flores, mujeres manidas de bolsos con cintas de colores y alimentos y velitas para el difunto. ${ }^{29}$ También podía verse algún que otro vendedor de comestibles ambulante que aprovechaba el tumulto para vender su mercadería, ${ }^{30}$ así como circunstanciales vendedores de flores y figuritas venerables. ${ }^{31}$ La contracara de la distancia que acechaba al muerto popular se materializaba en una devoción y un festejo que permanece en los intersticios e itinerarios populares. El intendente Daniel Infante promovió un ensayo de conectividad hacia el suburbio difuso del oeste, mediante un ómnibus que tuviese como dos puntos terminales el cementerio El Salvador y La Piedad. ${ }^{32}$ En esta prueba de conexión, se congregaban múltiples intereses que involucraban los impulsos de extensión de la «mancha» sobre esta porción de la trama urbana (MARTÍNEZ DE SAN VICENTE, 1986; RIGOTTI; MARTÍNEZ DE SAN VICENTE, 1991). Para consolidar el área como vendible y accesible a los sectores medios y obreros, la conectividad con las zonas centrales era un requisito absoluto. Pocos años después, embargados por la misma lógica, empresarios de tranvías observaban la rentabilidad de la extensión del transporte mecánico a esas latitudes, manteniendo como dos focos de atracción de población viajera a los Cemen- 
terios aludidos. ${ }^{33}$ Además de saldar una deuda de conexión, el proyecto argumentaba el mejoramiento, tanto de las condiciones de trabajo y circulación de los sectores populares como la valorización que el impulso circulatorio proporcionaría a esa zona del municipio condenada por la distancia a una segregación permanente. ${ }^{34}$

Paulatinamente, la inauguración de las líneas de tranvías hacia la zona Oeste, con epicentro en el cementerio de La Piedad configuraron, mediante la movilidad, un espacio que aun segregado de la zona central, desde entonces no estaba completamente incomunicado. ${ }^{35}$ Sin embargo, la conectividad siempre se pensó en términos del trayecto nodo central-suburbios. La suburbanidad escasamente lograría librarse de la distancia y la subordinación que la definía. ${ }^{36} \mathrm{~A}$ pesar de las promesas que el movimiento y la circulación (CASTRO GÓMEZ, 2009) auguraban al entorno deficiente del "cementerio de los pobres", pasados los años de 1920, éste era rehén de un abandono apenas atenuado por el incipiente poblamiento del barrio. La prensa colocaba al cementerio y la gente que visitaba a sus muertos en un cuadro sombrío de indefensión y pauperización. En primer lugar, se subrayaba deplorable acondicionamiento arquitectónico del solar, enfatizando su parquizado nulo y construcciones de pésima calidad:

En los días lluviosos, suele divisarse perdido entre la bruma provocada
por el agua, sobre el fondo gris, un grupo reducido de personas que
conducen trabajosamente sobre el fango, el cajón que guarda los
restos de un ser querido. El panorama adquiere contornos sombríos
entonces y el silbar del viento y el rumor de la lluvia tornan más
lúgubre el espectáculo de esa pobre gente, azotadas por todas las
miserias en la vida y obligadas a constatar cómo serán sepultadas
ante el ejemplo que presencian. En verano, bajo un sol implacable,
los cortejos fúnebres se pierden en las avenidas polvorientas sin una
sombra, sin un reparo. El largo trayecto, la fatiga y el calor obligan a
hacer altos en la marcha. ${ }^{37}$

Además, la afluencia de animales más o menos cimarrones vagando por los interiores destruía, ensuciaba y componía un escenario de desolación, ${ }^{38}$ sólo acorde a las gentes que por allí deambulaban en busca de un techo o como salvaguarda de la policía en el caso de los mendigos o rateros. No sólo la precariedad y la distancia emergen tras contemplar las significaciones de abandono y destrucción de las instalaciones. El servicio de sepelio para los pobres, gratuito en muchas ocasiones, alimentaba las representaciones de la segregación en los espacios de la muerte, transfiriendo el tabú de la pobreza y la desposesión al mismísimo cajón donde descansaba el malnacido.

Prácticamente resulta ineficaz el servicio tal cual está organizado y reglamentado puesto que se proporciona tan solo al que se presenta con un certificado de pobreza y el servicio consiste en un cajón muy ordinario que no tiene ni manijas, transporte del cadáver en una ambulancia común hasta el cementerio y una fosa por cinco años gratis en la Piedad únicamente. El solo hecho de que el solicitante destine los restos al Cementerio El Salvador, reemplace con un coche fúnebre a la mortera municipal o inhume en tierra paga, nicho o panteón, es suficiente para que pierda todos sus derechos del servicio gratuito. Solamente el indigente o pobre vergonzante, extremadamente necesitado, acepta este servicio que es pésimo y 
hasta cierto punto indecoroso para el menos exigente. ${ }^{39}$

Lo que aquí se intenta mostrar es cómo este espacio acumulaba, exhibía y profundizaba relaciones, prácticas e intervenciones que tenían al desperfecto como protagonista principal. Si se ahonda en el funcionamiento mismo de la institución, se observa cómo muchos de los empleados allí ocupados aprovechaban el nimbo de excepcionalidad denigrante acoplada a la distancia material y simbólica de la ciudad más o menos regular. Una denuncia, efectuada en el seno del HCD en 1929, desnuda el tráfico constante que el capataz y el jefe de la repartición hacían sobre el cuerpo desposeído de los enterrados. El pobre desposeído en vida era nuevamente ultrajado en la muerte con la profanación de las tumbas y los escasos ornamentos que las entornaban.

[...] Empezando por los traslados de cadáveres. Hechos a los pocos días de sepultados; lo que está terminantemente prohibido por la ordenanza municipal de la cual el Sr. Jefe cobra ha espalda de esta 70 pesos por cada traslado; que no hace más que poner en peligro a todos los obreros que desempeñan tales funciones, de verse contagiados por muchas y malas infecciones. Existen robos de coronas que el Sr. Capataz y jefe venden nuevamente a la casa donde fueron adquiridas por sus legítimos dueños. El macabro negocio con los dientes que extraen a los cráneos humanos; de lo cual es testigo el obrero emérito Barrenas, a quien le obligaron a hacer el sacrificio y por poco no se asfixio en el osario para sacar unas muelas (de oro) [.....$^{40}$

Pese a estas denuncias, una década después se solicitaban urgentes mecanismos de vigilancia para sosegar estas conductas que, sumadas a la frecuente falta de iluminación y asfaltado, propiciaban la delincuencia. ${ }^{41}$ Como corolario del blanco denigrante que había sedimentado en el camposanto del pobre, La Piedad fue el lugar escogido para erigir un horno crematorio de cadáveres que sumaba a la muerte el estigma de lo herético. En 1913, se sancionó una ordenanza que indicaba la construcción de un horno destinado a la incineración de restos humanos en el cementerio nuevo. La Comisión de Higiene y Moralidad creada Ad Hoc en el HCD sostenía que era la medida que permitiría controlar el acceso y difusión de males infectocontagiosos en el centro de la población mediante la eliminación certera en un paraje alejado de los gérmenes y microbios "que proliferan por mil entre las gentes de humilde condición". 42 Dilaciones presupuestarias y querellas ideológico-religiosas, retrasaron el proyecto por casi treinta años. En 1932, una discusión extensa en el seno del HCD, ${ }^{43}$ puso de relieve la necesidad de concretar el dilatado proyecto en el marco de un tinte administrativo «modernizador». La operación de quema de cuerpos, en primer lugar, estaba estipulada para los fallecidos en hospitales municipales o particulares y en segundo lugar para aquellos que por voluntad propia o familiar así lo dispusiesen. Este procedimiento era pensado también como agente liberador del espacio, mediante la eliminación de miles de huesos entregados al osario luego de años de enterramiento. ${ }^{44}$

Es interesante observar que los cadáveres provenientes de la Casa de Aislamiento serían entregados a la acción del fuego de manera sumaria. Un procedimiento particular para el caso de la cremación lo señala la indicación inalterable de realizar autopsias a los 
cuerpos que serían sometidos a la incineración. La manipulación de cuerpos y objetos, como se ha visto, era frecuente. El concurso de acciones reñidas con lo legal, profusas. Archivar a quién se quemaba, en la letra, significaba controlar la evanescencia que se abría tras la instalación de este dispositivo. No obstante la tipificación social de un cementerio con respecto al otro, el área que entornaba a El Salvador también acusaba algunos rasgos del desperfecto que por ser lugar de la muerte compartían. A fines de la década de 1920, paradójicamente el carácter pintoresco que se le quería dar a los entornos del Parque Independencia, mediante un proyecto de parquización en los alrededores del Cementerio El Salvador, quedaba desmerecido por las decenas de vacunos pertenecientes a cohortes de hacienda que mansamente circulaban hacia el Matadero Municipal". ${ }^{55}$ Quedaba clara la falta de relación o mejor la necesidad de desvincular el lugar de ocio y distinción, el jardín y los bosques del Parque de la Independencia de los procesos de entierro de cuerpos miserables. Al Cementerio El Salvador solo se permitiría el acceso de los féretros suntuosos escoltados por carruajes, mientras los cuerpos alojados en humildes cajones de pino y sin escoltas quedaban confinados a La Piedad. Tampoco los recorridos de los animales que se dirigían al brete de matanza podían empañar los atardeceres bucólicos del parque, la vida de la urbanización no podía mezclarse con ciertos entornos enjuiciados por su peligrosidad, falta de higiene o decoro.

\section{Hospital de alienados y topología moral}

Otra representación reñida con la regularidad, la norma y la moral es la del loco. Como esta expresión anómica ha sido analizada desde múltiples perspectivas, sólo se incardina aquí como otro sujeto más, capaz de congregar los mismos atributos asignados a la espacialidad segregada, aunque más difusos y con facultad siempre latente de circulación. Lo que aquí se muestra es cómo aparece en los enunciados aquel estatuto diferencial de un sujeto aun liberado de las instituciones de encierro, que estatutariamente se erigen como campo de batalla diferencial para las conductas desviadas (FOUCAULT, 2000). Entonces, el alienado, junto al hospital psiquiátrico, forma parte de esa espacialidad cuyos significantes están forjados por relaciones de estigmatización. ${ }^{46}$ Las fronteras entre diferentes tipificaciones de sujetos se ensancharon con el correr de las décadas, estableciendo diferenciaciones que implicaban un tutelaje especifico para cada una de ellas (CASTEL, 2009, p. 29; DONZELOT, 2008). No obstante, podemos hallar una comunidad de sentido que para lo que se quiere especificar aquí continuaba operativa. Por lo tanto, se pondrá en evidencia la cercanía que existía entre construcciones de sentido disímiles, pero que encontramos funcionando al unísono.

El espacio asignado a la locura en el hospicio fue un punto de llegada. Antes podemos hallar una asimilación profunda a los postulados, criterios de representación y universos de intervención del higienismo primero y la higiene social después (VEZZETTI, 1985, p. 44). Luego, la cercanía de esta especificidad del enfermo mental hallaría similitudes y comunidades con las de la institucionalidad penal sobre el delincuente (CAIMARI, 2004). Allí, antes 
que procedimientos médicos específicos, que sobrevendrían más tarde, la idea de la mantención de un orden que asegurase horizontes liberales de gobierno se soldaba a la interdicción de la circulación de estos cuerpos estigmatizables por el espacio urbano. La efigie del alienado, hasta la primera mitad del siglo XX, en la prensa local, aparece confundida con la del mendigo o el vagabundo. Esa figura, en primer lugar, distorsionaba un orden endeble $y$, en segundo término, configuraba una anomalía visual en el paisaje urbano moderno ${ }^{47}$

[...] Corresponde a la autoridad encargada de velar por la moral e higiene pública aplicar el remedio a estos males asilando a los que estén en condiciones de ser recogidos por su estado de miseria y/o desvarío mental sometiendo a la justicia a los que espoleen la caridad pública. ${ }^{48}$

La existencia de un Asilo de Mendigos y Dementes, regido por las Damas de Caridad a fines del siglo XIX, da cuenta de esta contigüidad. ${ }^{49}$ Allí, eran conducidos todos los sujetos que o bien deambulaban por las calles o no podian ser mantenidos por sus familias, debido a la falta de recursos económicos para enviarlos fuera de Rosario, o por cierta voluntad de abandono. Asimismo, las comisarias y cárcel de Rosario poseían alguna población de dementes que por conductas de agresión permanecían allí por falta de otra opción para proceder a su aislamiento.

Durante las dos primeras décadas de 1900, los sujetos observados por dolencias mentales comprobadas eran recibidos en los establecimientos especiales, construidos en Buenos Aires para tales fines. ${ }^{50}$ Así la voluntad alienista, paulatinamente, fue creando un espacio peculiar para esta figura que antes permanecía en el mismo horizonte de segregación que otros sujetos "desordenados" (ALLEVI, 2016).

\begin{abstract}
Mientras no se haga práctico el proyecto municipal de construir en el Rosario un asilo para los alienados, la autoridad respectiva debiera gestionar las mayores facilidades para la admisión de insanos en los establecimientos que existen en Buenos Aires [...] tenemos entendido que actualmente hay en la cárcel algunos penados locos que permanecen con los demás presos porque no se sabe donde remitirlos con la seguridad que encuentren el adecuado asilo. ${ }^{51}$
\end{abstract}

En 1917, se presentó un proyecto para la construcción de un asilo de alienados en el Hospital Rosario que fue desestimado por encontrarse en un sitio de proximidad al núcleo urbano poblado. Además, su entorno topográfico era efectivamente inviable para el desarrollo de actividades terapéuticas. Según las construcciones simbólicas y clínicas elaboradas por los alienistas, la idea de un entorno que propiciase el aislamiento de las familias y el desarrollo de una actividad productiva por parte del afectado precisaban de una espacialización peculiar, organizada por una arquitectura disciplinaria y psiquiátrica específica: «En sitios amenos y elevados y si es posible rodeados, de una extensa región rural». ${ }^{22}$

En 1922, se inaugura, en Rosario, un Hospital de Alienados para profundizar el estudio y tratar a la importante cantidad de afectados mentales de la ciudad..$^{53} \mathrm{El}$ argumento del aislamiento y reclusión en lugares totalmente desplazados de los núcleos poblacionales comienza a ser discutido por los médicos psiquiátricos. La ferocidad con que se había asi- 
milado a los locos con la delincuencia y la vagancia asumía ahora el formato de la terapéutica y la contención en la institución. ${ }^{54}$ No obstante, el funcionamiento de este Hospital no colmaba las expectativas totales de los directores y profesionales del establecimiento, que años después seguían insistiendo en la necesidad de dotar a la ciudad de otra institución de estas características y sin más sentenciaban: "El municipio debe saber de la existencia de esta columna de sujetos no amoldados al vivir social". ${ }^{55}$ La escenografía urbana abocetada por la prensa local, pese a estos cambios de paradigma nominativo, definía con los atributos de la anormalidad y monstruosidad a las conductas que desentonaban en el espacio más o menos regulado.

En los hospitales, en los establecimientos de alienados y aún por las calles de los centros urbanos, se ven, desgraciadamente, muchos ejemplares humanos que inspiran compasión. Son víctimas de la imprudencia, de la ignorancia o de la malevolencia. En esos lugares vemos a, los anormales, a los epilépticos, a los idiotas, dementes, etc. ${ }^{56}$

La figura de la segregación para estos individuos patologizados había adquirido caracteres más finos. El mejoramiento de la calidad mental de los sujetos, además de la eugenesia positiva sobre las poblaciones, hallaba un mecanismo de categorización más efectivo y sutil de la diferenciación y la distancia simbólica. ${ }^{57}$ Los mecanismos diferenciadores estarían bajo el control de una eugenesia profunda, instrumentada en la profilaxis mental. Como se estipuló para las enfermedades infectocontagiosas, a fines del siglo XIX y comienzos del XX, entonces el dispensario ceñía el itinerario espacial de las conductas desviadas atribuidas a trastornos mentales ${ }^{58}$

[...] el medio más eficiente para reconocer a los enfermos en sus más precoces manifestaciones morbosas que pueden así, mediante el precoz tratamiento, detenerse en su evolución; para investigar todos los componentes de la familia neuro o psicopática y así proporcionar los consejos o el tratamiento oportuno, para evitar la caída en la enfermedad; para establecer una lucha proficua en contra de los factores etiológicos de las enfermedades mentales y en fin, para ayudar económicamente (mediante trabajo o con remedios) a levantar la miseria de los verdaderos menesterosos, etc. [...] ¿Cómo llegar a la detección precoz? Luchando en contra de las causas más comunes de la alienación: La sífilis, el alcohol, la miseria, el trabajo exagerado, la tuberculosis, el contagio, etc. ${ }^{59}$

La definición de la especificidad del alienado como productor específico de conductas desviadas fue problemática y dificultosa. En principio, por habérselo juzgado parte de un conjunto de personajes que (sobre)vivían en los márgenes del orden social, a tal homologación respondía el título de Asilo de Mendigos y Dementes. Entonces esa corporalidad de contornos aun no estrictamente clasificables por la ciencia era vinculada a otra que se erigía como metáfora amenazante de la modernidad y del orden urbano regulado. El mendigo, como el loco, expresaban el desajuste del modelo de acumulación económica. Significaban la contradicción deambulante del sistema a los ojos de los que estaban ajetreados en su reproducción. Luego, el problema de la conducta desviada vinculó a los afectados de trastornos psicológicos y psiquiátricos con los criminales y produjo una segregación 
conjunta. Sólo tardíamente se convino en la especificidad de la segregación urbana que debía regir la vida de estos sujetos cuyas desviaciones contribuían a obstaculizar el funcionamiento del orden social.

\section{Prostitución/Vicio: La mujer en el laberinto regulatorio}

La prostitución en Rosario representa una singularidad para pensar los universos simbólicos de segregación. El sometimiento al reglamentarismo (1874-1932) ha permitido su estudio minucioso y sistemático a través del patrón espacial de localización en la ciudad, entre otros aspectos de una amplia historia sociocultural (MÚGICA, 2014). Aquí sólo se pondrán en relación algunas de las imágenes fraguadas que pueden compararse con otras de las examinadas para definir la periferización de una actividad más en la ciudad. Además, la consideración de universo de exclusión y estigmatización asume contornos especiales al referir al cuerpo de la mujer prostituta (GUY, 1994). Se pretende comprender por qué y cómo existen, en relación a los límites físicos para la prostitución, márgenes corporales cuya dotación de sentido exhibe poderes de contaminación hacia el resto de los espacios y relaciones contiguas a ello (DOUGLAS, 1973). La demarcación de radios para la práctica de la prostitución en la Casa de Tolerancia implica un límite que interseca niveles y texturas de peligrosidad y poder. Regular el margen es obliterar instancias de amenaza simbólica, la prostituta y su cuerpo abyecto estaba demasiado cerca.

Podemos observar la tensión manifiesta, latente, álgida o menguada, según las circunstancias, de tres fuerzas o grupos de actores interviniendo de múltiples formas sobre la cuestión de la prostitución en la ciudad. A fines del siglo XIX, fundamentalmente, la mayor cantidad de establecimientos donde se ofrecía sexo, sociabilidad, música y tragos se ubicaban en la zona de la aduana, próxima a las barrancas del Río Paraná, por donde afluían cientos de hombres que venían de ultramar. En 1874, se había establecido un radio para el desarrollo de la actividad completamente vulnerado, tanto en ubicación como en actividades desarrolladas dentro de los locales. ${ }^{60}$ En todo el período que dura la etapa de reglamentación, los radios fueron corridos, discutidos y redefinidos (MÚGICA, 2014), no obstante siempre el argumento del contagio y la decadencia moral fueron los significantes que monopolizaron el sentido. Hacia 1882, la reglamentación indicaba que las casas sólo podrían establecerse en un perímetro encerrado por las calles Corrientes, 3 de Febrero, $1^{\circ}$ de Mayo y La barranca. Todos los establecimientos que estuviesen fuera de ese radio debían moverse. Constantemente, el ritmo cotidiano de estas empresas violentaba las disposiciones. Los vecinos señalaban que estos "focos de inmundicias" permanecían en los lugares prohibidos o se desplazaban a zonas donde el espectáculo contra la moral y las buenas costumbres era igual o más peligroso. ${ }^{61}$ La comparación de la actividad con una suerte de enfermedad infectocontagiosa de naturaleza moral encabezaba las peticiones de los domiciliados en las zonas definidas o permitidas por la ordenanza. La distancia o la necesidad del desarrollo de la actividad en lugares bien alejados de la población "decente" parecía la solución circunstancial frente a este "mal necesario"62 
[...] el vecindario tuvo que soportar la fatal consecuencia de esa disposición viendo la implantación con toda su horrible desnudez una escuela del vicio y la corrupción. Así como para las enfermedades físicas de carácter contagioso se aísla a los pacientes en lugares apartados ¿Por qué para estas desgraciadas de enfermedades morales no se determinan igualmente lugares solitarios para que así no puedan con su contagio perjudicar a familias honradas? ${ }^{63}$

Los propietarios de las casas de tolerancia detallaban, para la defensa de su localización, un cierto carácter precario de sus entornos que podrían justificar el desarrollo de una actividad como la prostitución. Por ejemplo, en los reclamos puede verse que algunos opinaban que la decisión de eliminar las casas cercanas al mercado norte, "donde casi no había familias, solo fábricas y corralones", había resultado en la dispersión y desplazamiento del mal por diferentes sectores de la ciudad con las consecuencias que dicha "diseminación pútrida" traía aparejada. ${ }^{64}$ En 1888, la reglamentación se volvió más difusa. No se establecian radios específicos, sino que se definía cualitativamente la prohibición en "cuatro cuadras de cualquier edificio público, plazas y demás puntos de concurrencia", pudiendo la intendencia remover o desalojar casas que no cumplieran esta regla. La proliferación de peticiones fue notable. La inexistencia de radio fijo hizo que los propietarios intentaran argumentar que en su zona no existian tales instalaciones, no constituyendo el ejercicio de la prostitución en los locales un "agravio público". ${ }^{65}$ En 1892, un reglamento sobre la prostitución elaborado por el director de la Asistencia Pública disponía algunas características específicas que deberían respetar las casas del vicio. La prostitución sólo podría ser ejercida dentro del recinto íntimo de una casa de tolerancia inscripta. El deambular de mujeres exhibiendo su condición y oficiando clandestinamente era un problema importante. Interesa, también aquí, que la reglamentación sobre estas casas se asimilaba literalmente a las regulaciones existentes para las casas de inquilinato. La cantidad de pupilas debería coincidir con la cantidad de piezas y, desde afuera, no debería ser posible descifrar su estatuto de casa de prostitución para guardar las apariencias. Las persianas tendrían que ser fijas, los vidrios opacos o cubiertos de gruesos cortinados y sus mujeres inscriptas con libreta sanitaria. Las mujeres, por enfermedad leve o intención personal, antes de "salir a la sociedad" tendrían que pasar una temporada de tres meses en el Asilo Buen Pastor. ${ }^{66}$ Esa estancia de tres meses antes de abandonar esa actividad infecta, "pero necesaria", implicaba una normalización de esa mujer colocada en la frontera de lo permitido, sometida a un principio de exclusión contaminadora de su condición femenina, cosificada por la fuerza de las cosas. Para abandonar la prostitución, las mujeres quedaban prisioneras de una reeducación que habilitase, como una especie de salvoconducto purificador, su acoplamiento al resto de la "buena sociedad".

En 1893, un nuevo reglamento dispuso que ninguna casa de tolerancia pudiera instalarse entre las calles Dorrego, Cochabamba y el Río, otorgándoseles dos meses a las existentes para relocalizarse. ${ }^{67}$ Concomitantemente, vecinos de calles "importantes" (Córdoba, Santa Fe, Paraguay, Balcarce) del centro de la ciudad alegaban que era fundamental la 
expulsión de estas de las calles próximas a edificios oficiales, como el palacio de justicia. La persistencia de esta situación deshonraba y perjudicaba, en las alocuciones de los vecinos, a la Segunda Ciudad de la República generando una imagen indeseable de perdición y lumpenaje. ${ }^{68}$ Calle Santa Fe, por ejemplo, había sido dejada sin pavimentar lo que acoplaba el desperfecto urbano con disolución moral. Esta zona era señalada como "el barrio de las locas". 69 Paulatinamente y frente a la presión de los reglamentos las casas fueron asentándose sobre la calle Güemes, importante vía del barrio cercano a la Refinería. ${ }^{70}$ Inútilmente, algunos vecinos presionaron para impedir la concentración de las casas de tolerancia en el área donde residían o eran propietarios. El barrio según la prensa se convertiría, poco a poco, en el lazareto de emergencia de esa "Lepra Social" que era la prostitución. ${ }^{71}$ Nótese la vinculación de la mujer prostituta con el enfermo leproso y de la Casa de Tolerancia con la Casa de Aislamiento. Paralelamente a este proceso de localización más o menos concentrado, el sentido sobre el área central vinculado al vicio asumía otras formas. La prensa indicaba que como consecuencia de los desalojos efectuados en el centro, la zona estaba invadida por olas de clandestinismo. Deambulaban sin hora mujeres ligeras de ropa, esparciendo obscenidades a los transeúntes, ofreciendo su "carne impúdica". ${ }^{22}$ La solución era formulada como un interrogante que cristalizaba a la solución por la distancia como estrategia definitiva: “No hay en el Rosario arrabales deshabitados casi y por completo fuera de los ámbitos urbanos?" "Para trasladar sus orgías y sus vicios los que están reñidos con la sociedad, y no se mezclen a ésta viviendo en sus centros". ${ }^{73}$ Con el advenimiento del nuevo siglo y la experiencia de fijación de radios tibiamente exitosa, se decidió prohibir solamente de manera indeclinable la instalación y permanencia de Casas de Tolerancia en la totalidad de la calle Córdoba hasta el Bv. Santafecino (Oroño). Esta medida, argumentada por el intendente Lamas, señalaba que no era de tono moderno que una ciudad circunscribiera una sola zona a esa actividad y perjudicara y estigmatizara a un barrio entero con la mácula prostibularia. ${ }^{74}$ Por el contrario, se admitía la posibilidad de dispersión de las casas y la restricción de zonas de representación caras a la elite local.

\footnotetext{
[...] La actual reglamentación es deficiente y no alcanza a prevenir muchos casos que en la práctica son escollos que es preciso hacer desaparecer. Tolera y no tolera la prostitución, la permite y por otra parte pone trabas prohibitivas que obligan a las que la ejercen a servirse del engaño. Crea un privilegio para las que regentean la casa de tolerancia con prejuicio manifiesto de las que ejercen la prostitución. Invocando quizás razones inválidas se ha caído en el error de confinar a un determinado paraje a las prostitutas del municipio, y resulta que, toda aquella que no habita una casa de tolerancia en el radio designado y que ejerce la prostitución forzosamente cae en la pena que se establece para las clandestina aun cuando esté dispuesta a someterse a la inspección médica y a la vigilancia de la autoridad competente. ${ }^{75}$
}

Otras expresiones de la prensa, en El Municipio embestían esta resolución señalando que "pugnaba por invadir la ciudad y convertirla en una nueva Sodoma" ${ }^{76}$ Esta campaña de animosidad lanzada por El Municipio, el diario dirigido por Deolindo Muñoz, desnuda algunos planteos fecundos para lo que aquí se muestra. El atentado a la moral era vinculado a la 
proliferación de lo que antes estaba focalizado y medianamente controlado por los radios de exclusión, aunque, como hemos sugerido, ampliamente vulnerados y conflictivos. ${ }^{77} \mathrm{La}$ imagen que El Municipio construía era la de una Rosario "Infectada" por parias, truhanes y locas que podían en un futuro pasar a formar parte de la sociedad toda sin mácula ni señalización de ninguna especie, el peligro acechaba, según esta efigie en los nuevos inquilinos que la ciudad podría recibir. ${ }^{78}$

Como ha mostrado María Luisa Múgica (2014, p. 250), dos habían sido las estrategias para organizar el espacio urbano en relación a la prostitución. Por un lado, estaba la demarcación de un radio específico y, por otro, la diseminación de la práctica en toda la ciudad conservando algunos puntos como horizonte de exclusión absoluta. El municipio frente a las derivaciones, cosechadas por la reglamentación, planteó la necesidad de revisar la ordenanza. La posibilidad de extirpar el ejercicio de la prostitución fuera de los bulevares y encaminarla hacia los "suburbios" tropezaba con la paradoja de que estos parajes carecían de los servicios indispensables para la actividad reglamentada como iluminación, vigilancia, higiene. Todas agencias necesarias para controlar el desmadre que podría derivar en la permanencia de "un foco mortal" para la ciudad de Rosario. ${ }^{79}$ Fruto de este diagnóstico, otra vez se pusieron en acto estrategias prohibitivas fijas. ${ }^{80}$ La Capital planteaba que esta reglamentación propendía a edificar un núcleo fijo, gobernado por la inmoral y la inmundicia". ${ }^{81}$ Asimismo en contradicción entre las notas La Capital, se señalaba que el problema de la inmoral estaba disperso por toda la ciudad, vulnerando la posibilidad de evitar, segregar o ignorar un cúmulo de inmundicia y malas costumbres. ${ }^{82}$

\begin{abstract}
Además, centralizando demasiado los límites, se ha hecho demasiado extenso el radio permitido y esto conspira contra las facilidades de una fiscalización que debe ser constante y segura. Se ha dejado, pues, la obra a medio concluir. El Concejo no quiere poner resueltamente la mano en el centro enfermo y cauterizar. Tantea en los bordes y aplica paños tibios. Esto no es más que retardar la extirpación del cáncer, que habrá de hacerse, necesariamente, cuando haya menos resistencia en el seno de la corporación, es decir, cuando haya menos escrúpulos injustificados para operar cortando por lo sano. ${ }^{83}$
\end{abstract}

Pese a estas alarmas la fijación del radio siguió representando un problema para su implementación y las administradoras y dueñas de Casas de Tolerancia inundaban con misivas al HCD para prorrogar su estancia en lugares prohibidos y evitar el desalojo. ${ }^{84}$ Y los vecinos una y otra vez planteaban la necesidad de clausurar las que estuvieran cerca de sus domicilios:

[...]esa llaga social, que si bien es imposible extirpar, no lo es para aislarla, apartándola de los centros más populosos. -llevando esas casas a los barrios más apartados de la Ciudad como sucede en la capital federal y todas las Ciudades Europeas. ${ }^{85}$

Hasta 1914, estas vicisitudes experimentaron corrimientos y redefiniciones en los radios de exclusión, casi empleando los mismos significantes argumentales (MÚGICA, 2014) que denotaban las dificultades de la municipalidad para intervenir en el campo de la pros- 
titución. El barrio de Pichincha se configuró paulatinamente como área de instalación de las casas legales, significando una diferencia con la dispersión del ejercicio clandestino. Ese sector, actualmente patrimonializado sobre los cuerpos de la prostitución reglamentada, estaba cercano al industrial barrio de la Refinería o Estación Sunchales. Por casi 20 años, constituyó el espacio donde el foco prostibulario estaba aparentemente controlado. ${ }^{86}$

\section{Palabras Finales}

En este trabajo se ha querido auscultar y poner de manifiesto las cualidades que exhiben, en tanto formas comunes, algunas actividades encarnadas en corporeidades en la trama urbana. La edificación de umbrales de separación, segmentación y organización general del mundo urbano esta acoplada a ciertas prácticas e itinerarios sociales que encarnan dicho estatuto de separación. La abyección asociada a cuerpos, sujetos y prácticas como los enfermos infectocontagiosos, los cadáveres, los locos y las prostitutas muestran no sólo la inscripción material de los estigmas sino también la variabilidad de los contenidos estigmatizantes. Los cuerpos son en todos los casos mutilados en su cualidad humana, confinados al último eslabón de una jerarquía social. Mostrar la comunidad de significantes de impureza y distancia que organiza tal clasificación habilita la reflexividad sobre los contenidos que ingresan en la construcción de la otredad como principio organizador de los espacios. Asimismo el trabajo muestra cómo las clasificaciones sobre los espacios otros y sobre los cuerpos asimilados a estos son móviles, cambiantes de acuerdo a las distintas coyunturas y momentos en que se elaboran los marcos normativos que intentaban gobernar las conductas y las prácticas. La abyección como marca indeleble permite visualizar la conexión existente entre lo anómico o anormal y una imaginación sobre la regularidad que acompaña las construcciones de sentido sobre un deber ser de ciudad moderna.

La comprensión de las localizaciones desiguales basadas en la «funcionalización» de las ciudades ha respondido a una organización histórica de los significados asignados a lógicas de contaminación de prácticas y rituales socio-culturales designados como peligrosos, inmorales, desagradables e inconvenientes. Tales lógicas exhiben que los peligrosos son detectados por la constante contiguidad entre lo "sano" y lo "pútrido" como hemos podido detectar en los múltiples itinerarios de contacto en la ciudad. Este artículo ha propendido a observar tales cúmulos de sentido con la voluntad de desnaturalizar las definiciones que subyacen a toda organización socioespacial. Asimismo, ha puesto de relieve la importancia de aislar los significados asignados a los espacios tanto por los saberes como por las normativas que instituyeron la configuración urbana en una coyuntura específica. Las definiciones sobre los márgenes de intervención en las urbes siempre arrastran sentidos que operan sobre sujetos que se fugan de una normatividad imaginada. Visibilizar el carácter construido de la espacialización complejiza los alcances de la misma, pone en acto un ejercicio necesario sobre la dinámica permanente de la organización urbana, coloca la dimensión corporal de los sujetos otros en un terreno de disputa. 


\section{Bibliografía}

ALLEVI, José Ignacio. La profilaxis de la locura en la agenda política: saberes y técnicos de la Higiene Mental en la metamorfosis del Estado santafesino de entreguerras. Estudios Sociales del Estado, Buenos Aires, v. 2, n. 3, p. 65-98, 2016.

ARMUS, Diego. La ciudad impura: salud, tuberculosis y cultura en Buenos Aires, $1870-$ 1950. Buenos Aires: Edhasa, 2007.

CAIMARI, Lila. Apenas un delincuente: crimen, castigo y cultura en la Argentina, 18801955. Buenos Aires: Siglo veintiuno, 2004.

CASTEL, Robert. El Orden Psiquiatrico: La Edad de Oro del alienismo. Buenos Aires: Nueva Visión, 2009.

CASTRO GÓMEZ, Santiago. Tejidos oníricos: movilidad, capitalismo y biopolítica en Bogotá (1910-1930). Bogotá: Pontificia Universidad Javeriana de Bogotá, 2009.

DONZELOT, Jacques. La policía de las familias. Buenos Aires: Nueva visión, 2008.

DOUGLAS, Mary. Pureza y peligro: un análisis de los conceptos de contaminación y tabú. Buenos Aires: Siglo Veintiuno, 1973.

FOUCAULT, Michel. La vida de los hombres infames. La Plata: Altamira, 1996.

FOUCAULT, Michel. Defender la sociedad. Curso en el Collège de France (1975-1976). Buenos Aires: Fondo de Cultura Económica, 2000.

FOUCAULT, Michel. El cuerpo utópico: las heterotopías. Buenos Aires: Nueva Visión, 2010.

FOUCAULT, Michel. Los anormales. Curso en el Collège de France (1974-1975). Buenos Aires: Fondo de Cultura Económica, 2010.

GOFFMAN, Erving. Estigma: la identidad deteriorada. Buenos Aires: Editorial Amorrortu, 1995.

GUY, Donna. El sexo peligroso: la prostitución legal en Buenos Aires, 1895-1955. Buenos Aires: Sudamericana, 1994.

MACHEREY, Pierre. De Canguilhem a Foucault: la fuerza de las normas. Buenos Aires: Amorrortu, 2011. 
MARTÍNEZ DE SAN VICENTE, Isabel. Planes y proyectos para Rosario 1890-1910. Dana, Resistencia, n. 21, p. 23-35, 1986.

MúGICA, María Luisa. La ciudad de las Venus impúdicas: Rosario, historia y prostitución, 1874-1932. Rosario: Laborde, 2014.

PRIETO, Agustina. Rosario: epidemias, higiene e higienistas en la segunda mitad del siglo XIX. In: LOBATO, Mirta Z. (Ed.). Política, médicos y enfermedades: lecturas de historia de la salud. Mar del Plata: Biblos y Universidad de Mar del Plata, 1996. p. 57-71.

RAWSON, Guillermo. Conferencias de Higiene Pública. Paris: Donnanette \& Hattu, 1876.

ROLDÁN, Diego. Justificación, producción, usos y disputas de los espacios verdes en la Argentina El Parque Independencia de Rosario durante la primera mitad del siglo XX en Historelo. Revista de Historia Regional y Local, v. 7, n. 13, p. 189-222, 2015.

ROSENBERG, Charles. Framing Disease. Illness, Society and history. In: ROSENBERG, Charles; GOLDEN, Janet (Eds.). Framing Disease: studies in Cultural History. New Brunswick, New Jersey: Rutgers University Press, 1992. p. XIII-XXVI.

SAID, Edward. Orientalismo. Barcelona: DeBolsillo, 2002.

SALESSI, Jorge. Médicos, maleantes y maricas. Rosario: Beatriz Viterbo Editora, 2000.

SENNET, Richard. Carne y piedra: el cuerpo y la ciudad en la civilización occidental. Madrid: Alianza, 1997.

SONTAG, Susan. La enfermedad y sus metáforas: el Sida y sus metáforas. Madrid: Taurus, 2003.

VEZZETTI, Hugo. La Locura en la Argentina. Buenos Aires: Paidós, 1985.

WILDE, Eduardo. Curso de Higiene Pública. Buenos Aires: Imprenta y Librería de Mayo, 1878.

\section{Notas}

1 Memoria municipal de la intendencia de Gabriel Carrasco correspondiente al año 1890, Rosario, 1891, p. 190193.

2 Memoria municipal de la intendencia de Gabriel Carrasco..., p. 191.

3 Sobre construcción de la casa de aislamiento ETHCD 1894, f. 56.

4 Memoria Presentada al Honorable Concejo Deliberante por el Intendente Alberto Paz, Sola \& Uría, Rosario, 1897, p. VI. 
5 Memoria Presentada al Honorable Concejo Deliberante por el intendente Luis Lamas. La Capital, Rosario, 1901, p. 23.

6 Memoria Presentada al Honorable Concejo Deliberante por el Intendente Alberto Paz, Sola \& Uría, Rosario, 1897, p. 127.

7 Reglamento Interno de la Asistencia Pública de Rosario, Establecimiento tipográfico La Argentina, Rosario, 1905, p. 5-10.

8 Reglamento Interno de la Asistencia Pública..., p. 11.

9 Reglamento Interno de la Asistencia Pública..., p. 9.

10 Memoria presentada al Honorable Concejo Deliberante por el intendente Luis Lamas, La Capital, Rosario, 1901, p. XXVI.

11 patrón de segregación homogéneo con contenido variable. La Capital, 28 mar. 1906. En La Casa de Aislamiento. 12 La capital 5 mar. 1907 La infección pestosa y Cuestiones de salud pública.

13 Monos y Monadas, 14 ago. 1910, n. 10.

14 En 1926 se llamó a la organización de una comisión Investigadora de la administración sanitaria y hospitalaria DS HCD 10 set. 1926, p. 34-36.

15 DS HCD 11oct. 1927, p. 455.

16 DS HCD 11 oct.. 1927, p. 454. Referencias extraídas de la alocución del concejal Dr. Florentino en su discusión con el concejal Morcillo. Alli pueden identificarse dos posiciones con respecto a la dotación de una asignación presupuestaria para el mejoramiento de las instalaciones del Hospital Carrasco. Las denuncias de Florentino impactaban con las argumentaciones del bloque que acompañaba políticamente al Dr. Pignetto autor del analizado proyecto de Reorganización Sanitaria.

17 Digresión introducida por el Concejal Stoisa en DS HCD 11 oct. 1927, p. 456.

18 DS HCD 11 oct. 1927, p. 456. ET HCD 2 out. 1927 Ratificación de donación de terrenos en Barrio Belgrano f. 43218.

19 DS HCD 11 oct. 1927, p. 458.

20 Alocución del concejal Borla representante del Centro Unión Almaceneros DS HCD 11 oct. 1927, p. 459.

21 DS HCD 30 nov. 1928. Derogación decreto sobre habilitación dos pabellones para leprosos en el Hospital Carrasco.

22 ET HCD 13 nov. 1927. Carta desde la dirección de la Asistencia pública aconsejando a la intendencia que libere dos pabellones de tuberculosos (trasladándolos a la Clínica del Trabajo) para dar lugar al internamiento de atacados de Lepra. F. 3802. Asimismo en la nota se recomienda efectuar un censo de leproso para identificar la "cualidad y cantidad" del mal que acecha a la ciudad.

23 ET HCD 22 nov. 1928. La comisión vecinal de la sección octava del municipio eleva una carta al presidente del HCD informándole sobre el carácter escandaloso que reviste la existencia de leprosos en el Hospital Carrasco. Fs. 3805, 3806, 3807, 3808.

24 Existieron y existen otros enterratorios en la ciudad El cementerio de disidentes ubicado en las actuales instalaciones del Parque Independencia cambió de lugar al ubicado en el Bv. Avellaneda entre Pasco y Cochabamba a comienzos de siglo XX (cercano a la zona de la vieja Casa de Aislamiento, actual Hospital Carrasco) quedando los restos existentes alli en suspenso al parecer ET HCD 19 mar. 1932, f. 716.

25 Ordenanza art.1ํ O. 1 jul. 1874. Artículo 2631. Digestos y ordenanzas 1905.

26 ET HCD 11 dic. 1886 , f. 4-5.

27 ET HCD 1900, f.1-8.

28 A principios de siglo el "desierto" configurado por las dispersas e irregulares poblaciones asentadas al oeste del municipio figuraban como una problemática a resolver tanto por los emprendedores como para el municipio. La idea de una avenida diagonal que conectase zonas más centrales con esta porción formaban parte del universo de representación de intervención sobre el trazado. ET HCD 10 jun. 1902, f. 199.

29 ET HCD 30 oct. 1930, f. 1154. En 1930 aun con el servicio de tranvía funcionando con regularidad hacia el Cementerio La Piedad había que reforzar el servicio por la gran cantidad de gente que copaba las instalaciones en gran jolgorio para el día de los muertos.

30 La Capital, 3 nov. 1912. Día de los Muertos Jolgorio de a pie.

31 ET HCD 2 oct. 1928. Carta sobre regulación de los puestos de flores en el cementerio, f. 2617.

32 ET HCD 30 mayo 1911, f. 340.

33 ET HCD 18 jun. 1914, f. 205. ET HCD 1 ago. 1916 mensaje de la empresa de tranvías solicitando autorización para prolongar sus vías al cementerio La Piedad, f. 1. 
34 ET HCD 23 abr. 1914, f. 201.

35 ET HCD 17 feb. 1917. Compañía de Tranvías Eléctricos sobre inauguración línea N²0 al Cementerio La Piedad que se realizará el 21 feb. 1917.f. 17. ET HCD 20/01/1920 La Cia. de Tranvías eléctricos invita a los concejales a la inauguración de su línea que va a Cementerio la piedad en su prolongación al barrio Godoy. A celebrarse el viernes 25 ene. 1920. 4:30 pm, f. 4.

36 ET HCD 26 jun. 1926 "[...] el barrio Norte, el más populoso del municipio, continuara condenado a vivir aislado de los barrios Sáenz Peña, Mendoza, Belgrano y del Cementerio La Piedad, como también de Echesortu, pues el estado actual de la comunicación no se modifica en lo más mínimo, ni se amplían líneas que nos unan más directamente con los aludidos barrios", f. 23.

37 La Capital, 7 oct. 1931. El Cementerio La Piedad. Donde se entierran a los pobres.

38 ET HCD 7 jun. 1930. Solicitud de limpieza del Cementerio La Piedad de determinado sitios particularmente sucios y evitar que los animales se introduzcan y ensucien y destruyan las precarias instalaciones.

39 ET HCD 28 mar. 1932. Sobre la creación de un servicio fúnebre Municipal f. 4420 DS HCD 29 mar. 1932 Reglamentación ordenanza servicio fúnebre gratuito.

40 ET HCD 8 mar. 1929. Irregularidades que se cometen en el cementerio La Piedad. Carta de un vecino de barrio Godoy al HCD.

41 ET HCD 15 sept. 1939, f. 5501.

42 ET HCD 5 oct. 1913. Consideraciones de la comisión de Higiene y Moralidad., f. 16-19.

43 DS HCD 10 jun. 1932. Sobre Minuta de comunicación presentada por el bloque socialista "Hornos incineradores de cadáveres", p. 776-778. ET HCD 11 jun. 1932. Minuta de comunicación sobre el traslado del director de OP para un avista a la capital Federal para observar el procedimiento de funcionamiento de Hornos de cadáveres en el cementerio de la Chacarita, f. 3685.

44 Digestos 1931, p. 655-658.

45 La Capital, 11 sept. 1927. Mejoras en el Parque Independencia. La Capital, 7 sept. 1929. Notas de la ciudad. Tráfico de las haciendas.

46 La amplísima literatura en torno a la locura obliga a referenciar unos pocos autores y libros importantes para apoyar este muestreo Porter, 1999, 2002; Castel, 2009; Vezzetti, 1985; Pita, 2012; Birman, 1978; Barrán, 1992.

47 ET HCD 25 sept. 1904. Mediante una carta se solicita desde la dirección del mismo la ampliación del asilo de Dementes y mendigos pues está era la única forma de "luchar contra la mendicidad pública", f. 182-186.

48 ET HCD 9 nov. 1899. Proyecto de Ordenanza sobre la mendicidad en el municipio, puede observarse la confusión y asociación del demente con el mendigo, f. 347-348.

49 Municipalidad de Rosario de Santa Fe. Digesto Municipal 1860-1889, s/d, p. 80-81 y DMR 1892-1895, Jacobo Peuser, Buenos Aires, 1898, p. 667-668.

50 CONI, Emilio; MELÉNDEZ, Lucio. Consideraciones sobre la estadistica de la enajenación mental en la Provincia de Buenos Aires. Buenos Aires: Imprenta Coni, 1880, p. 24.

51 La Capital, jueves 12 abr. 1906. Dementes.

52 ET HCD 3 mar. 1917. Construcción Sección alienados en el hospital Rosario, f. 507.

53 La Capital 1 oct. 1927. Hospicio de alienados.

$54 \mathrm{FOZ}$, Antonio. El problema de la asistencia psiquiátrica en el Rosario. Boletín del Instituto Psiquiátrico, Facultad de Ciencias Médicas del Rosario, año VI, n. 19, p. 1-120, oct. 1933-sep. 1934.

55 ET HCD 13 jun. 1932, f. 4052.

56 La Capital, 16 ene. 1931. Institutos de Eugenesia.

57 FOZ, Antonio. El problema de la asistencia psiquiátrica..., p. 100-101.

58 El Horizonte de organización científico institucional proyectado por los profesionales de la psiquiatría en Rosario se basaba en; a) Tratamiento de los enfermos agudos en el Hospital psiquiátrico actual) Que los crónicos se asistan en un establecimiento tipo colonia alejado de la ciudad. Cf. FOZ, Antonio. El problema de la asistencia psiquiátrica..., p. 102.

59 FOZ, Antonio. El problema de la asistencia psiquiátrica..., p. 103-104.

60 ETHCD. Año 1864-1874. T. N 1, f. 593. La Capital, 2 abr. 1874. Radio aceptado y 6 mayo 1874 Radio Moral.

61 ET HCD. Año 1885. T. N 10, f. 273, nota del 20 sept. 1884, firmas de vecinos. Nota del 25 sept. 1884 , f. 272.

62 ET HCD por varias comisiones. Año 1886. T. N 14, f. 511-514. El 2 abr. 1887 no se hizo lugar y se archivó. La Capital, 14 feb. 1886, también 22/8/1886 solicitaba despacho favorable para la petición de los vecinos de la zona norte.

63 ET HCD, 14 abr. 1885. 
64 Notas y Documentos municipales, Año 1885. T. № 10, f. 10, f. 9-11. La nota de los propietarios de burdeles estaba firmada por José Chandel y Juan Sabattié, ya citado. Nota del 27 ene. 1885, había unas 44 firmas, varios colocaban Mercado Norte. Indicaban que la zona mencionada era un paraje completamente aislado ya que el único vecindario lo constituía una fábrica de café, una barraca, cuatro corralones de carros, un conventillo y algunos almacenes al menudeo, careciendo de moradores.

65 ET HCD. Año 1888, T. Nº 17, f. 509-514.

66 ET HCD 22 abr. 1892. Reglamento prostitución f. 193.

67 DM 1892-1895, p. 1240-1241 ET HCD. Año 1892. Marzo abril. T. N² 28, f. 193 y ET HCD. Año 1893. Abril-junio. T. N 32, f.125-126, 235. Actas del Concejo Deliberante, T. N 4, sesión del 11 jul. 1892, f. 126-143 e Ídem, T. № 5 , sesión 3 abr. 1893, p. 212, 216-217.

68 ET HCD. Año 1893. Jul.-dic.. T. N³3, f. 45.

69 ET HCD. Año 1893. Jul.-dic. T. N 33, f. 51-53. Febrero 241893 varios vecinos ejercieron derecho de petición para desalojar casas de tolerancia sitas desde la calle Santa Fe desde Paraguay hasta Balcarce y de la de Independencia desde San Lorenzo hasta Rioja. "La verdad no puede hermanarse con el vicio, los tribunales que son el templo de la moral no deben confundirse en un solo grupo con las asquerosas prostitutas focos de corrupción e inmoralidad", f. 45.

70 Así se popularizó el nombre del barrio cercano a la Refinería de azúcar instalada en 1887 desde donde salían los cargamentos de azúcar en bruto por el embarcadero en el area norte de la ciudad. Esta zona estuvo marcada por el contenido obrero de sus habitantes.

71 La Capital, 5 dic. 1894. Moralidad y pudor. Vicio y corrupción. Inocencia y virtud.

72 ET HCD 13 jul. 1900, f. 222. Sobre prostitución reglamentada "A medida que el crecimiento de una ciudad aumenta se presenta más difícil el problema de la organización de la prostitución. Escapa a la vigilancia y fiscalización de las autoridades el ejercicio de aquella, en la forma que se llama clandestina, y los peligros son mayores porque no es posible invadir la libertad de acción de las personas, sin caer en el extremo vicioso del abuso".

73 La Capital, 23 dic. 1893. El clandestinismo un mal que amenaza.

74 La Capital, 20 nov. 1900. Reglamentación de las casas de tolerancia.

75 ET HCD, 13 jul. 1900, f. 222-223.

76 El Municipio, 14 nov. 1900. La prostitución libre. Una ignominia municipal.

77 Con esta idea de proliferación de los burdeles se dictó una ordenanza de asistencia médica a las camareras de café que potencialmente podian dedicarse a la prostitución estigmatizando una actividad que aunque en ocasione coincidía no era exclusiva ET HCD 24 ene. 1900, f. 61-62.

78 Sobre la base de estas construcción de sentido en 1907 se amplia la ordenanza sobre conventillos y fondas dictada en 1891 a las fondas y cafés refugio de la prostitución clandestina ET HCD 24 sept. 1907, f. 124. Actualmente la instalación de cafés posadas y fondas en el barrio de los prostíbulos se hace con preferencia en las casas de inquilinato, porque estas sirven para ocultar o disimular la prostitución, estorbando a su descubrimiento y acción correctiva de las autoridades.

79 ETHCD 1903. Ene.-dic. T. № 53, f. 451-457.

80 El 15 de diciembre de 1903, se determinó que las casas de 1a categoría se debían establecer fuera de las calles Tucumán, al norte; al sur, 9 de Julio; al este, 25 de Diciembre y al oeste, Independencia (Pte. Roca) y para las casas de $2^{\text {a }}$ categoría la zona de prohibición era más amplia: por el norte, Av. Wheelwright; por el sur, Montevideo; al este, 1 de Mayo y al oeste, Balcarce

81 La Capital, 17 dic. 1903. Por la moral. Una obra a medias.

82 La Capital, 29 ago. 1903. Los báratros de la moral.

83 La Capital, 28 ago. 1903. Infección social. Propagación de los focos.

84 ET HCD, Año 1904. Ene.-sep. T. № 54. Carta del 27 feb. 1904. Ibidem, f. 123, nota del 9/3/1904 y folios $124-125$. 85 ET HCD nov. 19094 jun. 1909 f. 31. La ordenanza que solicitamos a la comuna, se impone como medida necesaria para ayudar al adelanto material de otros barrios apartados, pues, no es posible ocultar que las pingues rentas que producen al capital empleado en los edificios necesarios para el funcionamiento de esas casas, traen aparejada la edificación forzosa y abundante, que luego, la evolución del progreso de los pueblos, transforma en centros de comercio lícito y labor fecunda. Acompañan más de 100 firmas.

86 Libre Palabra el 21 ago. 1926, 29 mayo 1926. El Nacional el 18 abr. 1928. 
Cecilia María PASCUAL. Doctora en Humanidades y Artes. Profesora Adjunta de la Cátedra Espacio \& Sociedad de la Facultad de Humanidades y Artes, Rosario, Argentina y Becaria postdoctoral de CONICET.

Recebido em 16/09/2016

Aprovado em 25/01/2017 